\title{
THE RELATION OF LOCAL GOVERNMENT STRUCTURE TO URBAN RENEWAL
}

\author{
GEORGE S. DUgGa*
}

Enthusiasts for a municipal activity which demands wide cooperation from all corners of local government are often likely to favor a clear hierarchy of authority, in which the policy is formulated at the top level of local government-whether it be mayor, council, or city manager-and then is put into effect from above. On the other hand, enthusiasts for a narrowly limited and self-contained activity are likely to favor granting to the organization responsible for the activity a substantial independence from the usual city hall chain of command. Since urban renewal requires both the widespread cooperation of many existing local government departments and agencies and the pursuit of some relatively limited and self-contained new activities, it is understandable that there has been no generally accepted doctrine as to which local government structure is the best for accomplishing urban renewal.

Adding to the complexity of discovering an optimum municipal organization for urban renewal is the fact that the administration of a redevelopment program does not end at the local level. Federally aided local renewal programs involve the close participation of the federal government-as well as that of private organizations, business firms, civic associations, neighborhood groups, and many others. How may all these elements best be coordinated?

Urban renewal is not so narrow and so immediate an objective that renewal enthusiasts dare neglect general local government procedures or authority structure. It is not so broad an objective that whatever contributes to good procedure and executive power, in general, will necessarily be good for urban renewal. Renewal involves "middle-range" objectives which demand both a certain freedom of action in limited fields, and some centralization of responsibility and authority in local government. In this connection, consider the recent observation of a businessman that "in the past we have generally thought of municipal operations as separate and distinct service functions-police, fire, schools, zoning, sanitation, and so forth ... the greatest impact of federal programs for urban renewal has been to change completely our purposes and aims of city government. While municipal services continue to be important, we must now look additionally for local governments to think in terms of the economic growth and development of the community."1

- B.A. 1936, M.A. 1937, Unirersity of Wisconsin; A.M. 1944, Ph.D. 1956, Harvard University. Public Administration Analyst, Bureau of Public Administration, University of Califoraiz (Berkeley), since 2952.

${ }^{1}$ Palmer, National Programs Affecting Urban Economic Grosuth, in Comsittek for Econourc Deveropmext, Tae Lithle Economies: Problems of Usited States Area Development 48 (1958). 


\section{The Urban Renewal Enterprise}

Because of this dual focus of urban renewal, it may be helpful to examine urban renewal as an enterprise. An enterprise is defined is "an attempt or project, especially one which involves activity, courage, energy, or the like; an important undertaking."2 A description of local government organization in urban renewal may appropriately begin with this awareness that widely varying participants engage together in an activity having important substantive goals, demanding a high level of activity, and calling for a forward-looking and venturesome frame of mind in which prospects are weighed and a strategy developed to overcome anticipated obstacles. This is a special type of administration. The activities which the literature of administration illuminates range from routine to innovative, from the largely habitual to the freshly planned.' We must be prepared for a large measure of innovative management and freshly planned organization when we attempt to describe the administration of urban renewal.

The concept of an enterprise is important not only for what it is, but also for what it is not. An enterprise is not necessarily fully recognized from the start by all its participants; and it may have a structure different from that of any of the formal organizations which participate in it. To be sure, an enterprise's structure may parallel that of a formal organization; but the differences between an enterprise and a formal organization, as well as the rather abstract similarities, are impertant for our purposes. A formal organization may participate in several enterprises, and an enterprise may depend upon the participation of several formal independent organizations. The most familiar example of an enterprise may be a construction project in which are associated, for the time being, several independent

2 Webster's New International Dictionary of the Exglish Language 853 (2d ed. unabridged, 1950).

The literature of administrative analysis attempts to formulate general perspectives for understanding local organization. Sometimes the emphasis is on a goal or goal cluster such as "efficiency and conomy," sometimes on a method such as "scientific administration," sometimes on realistic analysis of power as in the "pressure group" (or "interest group") and "community power structure" approaches. Sometimes social psychology is stressed in" the analytical scheme. Each of the perspoctives has added to a general understanding of administration; but at present, we are left with a description which concentrates on one organization at a time and on its "equilibrium" condition, rather than its process of organizing and changing. While there is no one work which calls itself a history of administrative doctrine, articles and collections of readings provide an overview. American administration in the I940's was summarized in four articles in the Public Adminstration Reziew, three of which are relevant here: Gaus, Trends in the Theory of Public Administration, ro PeB. Adusw. Rev. 161 (1950); Aseher, Trends of a Decade in Administrative Practices, id. at 229; Sayre, Trends of a Decade in Administrative Values, 11 id. I (195I). Summary history of administrative philosophy is provided in Sayre, Premises of Public Admin. sstration: Past and Emerging, 18 id. 102 (1958); and Stover, Changing Patterns in the Philosophy of Management, 18 id. 21 (1958). The philosophy of public administration is analyzed comprehensively in Dwigrt Waldo, The Adirisistrative State: A Stzdy of the Political Theory of Amerucan Pudlic Adisisistration (1948), which also contains a selected bibliography on the development of administrative theory. Three collections of administrative readings are: Albert LepawsK,, ADsunistration: THe Ant and Sctence of Organizition and Mlaskgexiest (1955); Felix Nigro, Public Adduinistration Rzadings aid Documents (195I); and Dwiget Waldo, Ideas and Issues in Public Adoministaktion (1953). 
organizations, a client, architects, engineers, contractors, subcontractors, and local building inspectors-all ordinarily independent but all cooperating in one way or another in a project.

All federally aided local urban renewal enterprises draw upon the federal government, some local government or governments, some private firms acting as redevelopers or rehabilitators, some households and firms which own affected property, some civic organizations as supporters or opponents of urban renewal, and the mass media as channels of communication and information. It is difficult to coordinate all of these elements within the framework of a particular local situation. Nonetheless, the relationships, one to the other, of these different participants in the urban renewal enterprise cannot be neglected-nor the import of those relationships in determining which kind of internal organization in local government is most suitable for renewal. What guidance does the enterprise perspective offer toward the optimum form of local government structure for accomplishing urban renewal?

Obviously, not all interested citizen organizations can be lumped together (like a united fund, or community chest) into a single superorganization. And even if this were possible, it would still be necessary to allow for the role of the federal government, mass media, and "the market" for blighted and redeveloped properties. Furthermore, account must be taken of the varying degrees of independence among different local governments-and even among the units nominally within one local government. For instance, the territorial fractionation displayed in metropolitan areas, which contain on the average about roo local governments each, may affect urban renewal. And surely it is not unimportant to urban renewal in a central city when a ring of suburbs maintains building and subdivision standards which discourage construction of low- and middle-value residential housing, or when a suburban government opposes dispersion of minority ethnic groups.

Overlying government units may also have their effect, favorable or unfavorable. For instance, the actions of the county government may affect solution of the relocation and rehousing problems. And the independent school board or district may be enthusiastic about the opportunity through urban renewal to enlarge school playgrounds and improve the surrounding area as a residential neighborhood. In other words, many activities important to urban renewal lie outside the local government's direct control-irrespective of the internal structure of the local government itself.

Consider also the formally independent municipal bodies politic and corporate, such as the thousand or more housing authorities (many authorized to conduct redevelopment), and the hundreds of similarly constituted redevelopment agencies. Also, bodies within city government-such as planning or zoning commissions, or boards of adjustment-may be possessed of a degree of independence, and often are headed by a board with long, staggered terms or by a directly elected official.

-Nat'l Ass's op Housing and Redevelopment Officials, Housing and Urban Renewal Directory 232 (1958). 
Moreover, the units important in urban renewal may be so widely and thinly scattered among major city government departments that no department head would make urban renewal his major responsibility. In this event, which would better accord with renewal administrative needs-superimposing a renewal staff coordinator over all local government renewal activities, or transferring some to a new line "Department for Urban Renewal"?

In practice, many cities do not bother to use either alternative. Among 242 cities of 5,000 or more population which reported on the coordination of renewal in a survey conducted in $195^{8}$, only $15^{8}$ reported a central agency or official coordinating or administering "a substantial amount of the urban renewal program." The other thirty-five per cent did not claim to have a central agency. Furthermore, some of the central agencies are merely committees; of the 158 cities, only 127 had a full-time director of the central renewal agency. In fifty-three of these 127 cities, the director of the central agency was appointed by a corporately independent redevelopment or renewal agency, which may not have authority over any city department and nowhere exerts police power for enforcement of ordinances governing the conditions or construction of housing. " There, in terms of formal organization, the "central" agency was not in a position to insist on coordination among the enforcement agencies and the redevelopment and public housing activities.

Even when the central coordinating agency for urban renewal is itself part of the city government, it ordinarily lacks some of the formal authority to obtain absolute adherence to its decisions. In the survey, this held true of all the full-time directors of central renewal agencies-thirty-one appointed by city managers, twentyone by mayors, and seven by çity councils.

\section{II}

\section{Historical Influences and Federal Requiremants}

Certain historical influences are reflected today in the municipal organizational structure within which urban renewal must operate. The professionalization of city government which was accelerated by the reform movement in the second half of the nineteenth century was eventually extended to the chief executive in the form of council-manager government-which also ordinarily strengthened the entire hierarchy of authority in city government. However, even in council-manager cities,

- The literature of administration calls for supplementing the executive model by grouping activities "like" in purpose, process, clientele, or scrvice area. See, e.g., Luther Gulick \& Lyndall URwick (EDs.), Papers on the Science of Administration 15 (1937). The idea that a group of activities are "like" in the sense that they serve renewal purposes, or follow renewal processes, or serve a renewal clientele, or come to bear on renewal areas assumes at least a potential renewal enterprise. That potential enterprise is defined by the opportunities indicated by federal and state legislation and by the local situation and by experience in other localities which have availed themselves of similar opportunities.

- Lange, Housing and Urban Renewal Redevelopments in 1958, in Internatjonal City Managers Ass's, Municipal. YeAr Book 324 (1959).

${ }^{3}$ One model state enabling act circulating in 1953 propasing police powers for Conservation Authorities is reviewed in Jack M. Siegel \& C. Williax Brooks, Szum Prevention Through Conservation AND Reimailitation 139 (1953). 
there are marked variations today in the extent to which a well-defined hierarchy of authority exists in such local government. Still less hierarchical are some of the cities having mayor-council government and the thirteen per cent of American cities of 5,000 persons or more which have commission government. ${ }^{8}$

The Great Depression encouraged establishment of municipal tax and debt. limitations; and these limitations are, of course, very significant in the allocation of municipal resources for urban renewal. Furthermore, during the Depression, a number of independent authorities were spawned, which in many instances became. models for urban renewal commissions or were themselves entrusted with responsibility for the urban renewal ent=rprise. Under the Housing Act of $19377^{9}$ annual grants were made to local housing authorities, which were separate corporate bodies. and which, on the basis of promised federal grants and anticipated rents from public housing projects, could borrow funds to build the projects. Since the debt was. incurred by the housing authority, rather than the city, an escape was provided from debt limits which the downward drift of assessed values during the Depression had. made especially onerous. The corporate authority device had obvious relevance as a means for freeing urban renewal enterprises from municipal debt limitations. On the other hand, the relative independence of the corporate authority-due to long, staggered terms of the members of their governing boards ${ }^{10}$ and freedom from: personnel and budgetary controls-presented problems in coordination.

Federal requirements are relevant for the distribution of authority among private, municipal, and federal participants. The Declaration of National Housing Policy emphasizes private participation and local gavernment responsibility. ${ }^{11}$ Theemphasis on private enterprise is expressed further through project planning procedures which call for evaluation of the project's soundness in terms of market: demand. The emphasis on citizen participation is manifested in the workableprogram requirement with respect to such participation, and through provisions for public hearings. The emphasis on local government responsibility is seen in requirements that each project application have the approval of the local governing body. and each workable program bear the signature of the city's chief executive.

- See section on governmental data in Int'z City Managers Ass'N, Munjcipal Year Book (annually).

- 50 Stat. 891, 42 U.S.C. $\$ 1409$ (1958).

${ }^{20}$ Typically, 2 commission of from three to seven members, usually five, heads the local housing authority. Terms ordinarily do not exceed five years, but commissioncrs may be reappointed. CAs. Health \& Safety CODE 34272 ; Itl. AnN. Stats. ch. 671/22 3 (I959); Micls. Comp. Laws ch. 125. (1952); Mo. Rev. Stat. ch. 99 (1956); Oho Rev. Code Service ANn. 3735.01 (1956); Pa. Stat. AnN. tit. 35, ch. 18, 1545 (1956); TENN. CODE ANN. tit. 13, ch. 9 (1956). Note that in Ohio, only two. members of five on a metropolitan housing authority are appointed by the mayor. Two are appointed by courts and one by the board of county commissioners.

${ }^{12} 63$ Stat. 413 (1949), 42 U.S.C. \$ 145 I (1958). State statutes do not greatly change the breadth of goals, since the statements of purpose in the statutes of the several states confarm so closely to national legislation and to each other. Indeed, the state enabling statutes tend to be kept in conformity with federal legislation as it is amended, so that the localities may be in a position to utilize all available federal . aid whatever the current emphasis. In taking property by eminent domain, the use of the taxing power. and so forth, state constitutional restrictions do, however, sometimes hover in the background as a limitation on the objectives which can be pursued under urban renewal. 
Contrasting with these unequivocal procedures is the circumspect federal language concerning the structure within local government. The National Housing Act of I949 refers to a local public agency as "any State, county, municipality, or other governmental entity or public body, or two or more such entities or public bodics, authorized to undertake the project for which assistance is sought."12 To apply prior expertise obtained with publicly financed low-rent housing, many states assigned redevelopment to local housing authorities as an additional duty-and some. times formally redesignated them housing and redevelopment authorities. Other states provided for a new type of. authority with its own governing commission, executive director, and staff-a structure similar to the housing authority's. A few states quite early enabled city governments themselves to conduct redevelopment operations or permitted local choice of administrative structure. In federal language, these are all referred to as "local public agencies."

Of key importance has been the broad definition of local public agency (LPA). The federal government contracts with it; but its meaning varies from place to place according to the types permitted by state laws. Under the Housing Act of 1949, few states enabled the city to be its own local public agency; ${ }^{23}$ the role of the city government was limited. City Council approval of project plans was, however, required as a condition of federal aids. An early form of model state enabling legislation suggested by the Housing and Home Finance Agency (HHFA) offered no inducement for states to permit local choice of the type of LPA. However, subsequent to the Housing Act of 1954, HHFA proposed an enabling statute designed to encourage more local experimentation, and specifically to place the city government and its chief executive in an important role; under this proposal, urban renewal authority would be "conferred on the municipality itself or on one of several other prescribed public bodies selected by the municipality." For states with enabling legislation which followed the earlier model, HHFA stood ready to aid in modifying legislation to permit greater local option. Under the Housing Act of I949 and related federal regulations, the only city official whose signature had to appear on applications was one "required to sign" under state law or one who served as "recording officer" for the local governing body. The city's chief executive came into a formal role in federal project regulations in $1954:^{\text {: }}$

When it appears from the initial application for an advance of Federal funds for an urban renewal project that the proposed project will involve activities to be carried out by some entity other than the Local Public Agency submitting the application-such as the municipality-it will be necessary that the application be accompanied by satisfactory evidence that such other entity will actually carry out such activities and has the capacity to do so. Such evidence may consist of an appropriate statement of the chief executive of such entity.

${ }^{12} 63$ Stat. 420,42 U.S.C. $\$ 1460$ (h) (1958).

${ }^{13}$ Among the early oncs were Michigan, New York, and Ohio.

24 Urban Renewal Administration, Local Public Agency Letter No. 45, 1954, pp. 1-r4. 
The Local Public Agency Letter outlining this requirement also suggested that "consideration may be given by the community to the desirability of establishing an office for the over-all coordination of urban renewal activities in the community." While there is no requirement that this be a city official, it is noted that, "in some cities, a coordinator for such purposes has been appointed by the mayor, and such coordinator reports directly to the mayor respecting the performance of his functions."'15

The fourth of the seven elements of the Workable Program requires "a firmly established administrative responsibility and capacity for enforcement of codes and ordinances and for carrying out renewal programs and projects."16 This has not been used as a springboard for the federal government to leap into the local organization pool. Examination of regional office memoranda on the subject indicates that the requirement has been brought to bear chiefly on code enforcement agencies, and there chiefly to assure that personnel will be adequate. Federal literature suggests that "a local official be assigned the responsibility for preparing for the signature of the chief executive of the local government an application for initial certification of a workable program,"17 but this official need not be a subordinate of the city executive. Indeed, in many cities, the Workable Program is prepared by the staff of a corporate authority; in some cities, by planning commission staff; in others, by a consulting firm. It is by no means settled that the immediate staff of the chief executive prepares the Workable Program.

III

Relationship Between Urban Renewal Achievement and Form of Government

In pursuit of the broad objectives set forth in federal and state statutes, a renewal program is locally developed which can induce the participation of several formally independent organizations and individuals. Within the generally blighted area, a particular portion is chosen as the first project. It may be chosen not because it is the most blighted portion, but because the market for renewed property there is most assured, or because the owners of property there have the financial credit which most readily permits them to participate, or because in this section there is a local organization which best assures neighborhood communication and cooperation, or because the location is so prominent that its renewal will demonstrate the program to most of the city's citizens.

As urban renewal proceeds into the first project and beyond to later projects, there will be ebbs and flows in active participation and public interest. Of course, the execution of a project will be widely regarded as the single great moment for changing the character of an area, so that public interest will be heightened in this

\footnotetext{
15 Ibid.

30 Housing and Home Finance Agency, How Localities Can Develop a Workable Program for URaA Renewal 8 (1956).

${ }^{17}$ Id. at 3 .
} 
stage. And perhaps the long preparation and planning for the project or the struggles of disposition will be less actively supported by the public. Perhaps, too, one project will attract special attention, and everything later will seem anticlimactic.

Under these circumstances, to achieve both the early accomplishment of statutory objectives and the building of an enterprise with assured continuity sufficient to complete the urban renewal task, a strategy is needed which will guide the choices to be made between myriad competing alternatives. ${ }^{18}$ The standard for evaluating urban renewal achievement must reffect this variability of strategy and must reckon not only how much has been accomplished, but also how much now appears probable of accomplishment.

In order to evaluate urban renewal achievement at the local level, the writer surveyed the renewal enterprises of cities distributed throughout the United States, under a grant from the Urban Renewal Administration. As a first step in the study, the ninety-three cities which by mid-r 957 had advanced at least one renewal project to the execution stage were analyzed by type of government (council-manager or mayor-council), type of LPA (city, redevelopment authority, or housing and redevelopment authority), date of entry into the urban renewal program, speed of progress, and population. ${ }^{19}$ Because a skewed distribution resulted when form of government and type of LPA were listed by population size, cities at the population extremes were eliminated (approximately one-third of all cities studied). This helped to clarify the effect the form of government and type of LPA had on progress. The study of progress to July, 1957, showed that:

I. Once having entered the program, cities with different general forms of

${ }^{18}$ The choices, of course, are limited in many respects by reason of the procedures prescribed in federal and state legislation and regulations. For instance, the federal statutory emphasis on cooperation between public and private participants tends to receive strong local support and itself becomes both a program objective and a determinant of the authority of each urban renewal participant. State laws may determine the form of local government organization. As a consequence of these constraints, the local choices are more in the nature of alternatives for cultivating a given seed, rather than for creating 2 new product. to

\begin{tabular}{|c|c|c|c|c|c|}
\hline Form of Organization & $\begin{array}{c}\text { Cities of } 5,000 \text { or more Population } \\
\text { in U.S. End of } 1957\end{array}$ & Citie & In & $\begin{array}{c}\text { ive in Renes } \\
\text { July, 195 } \\
\text { Project } \\
\text { Execution }\end{array}$ & val Program, \\
\hline Mayor-council & $\begin{array}{r}1,297 \\
834\end{array}$ & $\begin{array}{l}94 \\
60\end{array}$ & & 45 & 10 \\
\hline $\begin{array}{l}\text { Council-manager } \\
\text { Other forms }\end{array}$ & $\begin{array}{c}834 \\
422 \\
\text { l. Project Directory }\end{array}$ & 54 & & $\begin{array}{l}22 \\
26\end{array}$ & 0 \\
\hline $\begin{array}{l}\text { City as LPA } \\
\text { Housing and redevelopment }\end{array}$ & 42 & 40 & & ro & $6 \cdot$ \\
\hline $\begin{array}{l}\text { authority as LPA } \\
\text { Redevelopment authority }\end{array}$ & 107 & 89 & & 54 & 6 \\
\hline as $\mathbf{L P A}$ & 101 & 79 & & 36 & 6 \\
\hline
\end{tabular}

Sources: Data on numbers of cities in program are from HHFA. Total numbers of cities of 5,000 or more population by form of government are from Int'L Ciry Managers Ass's, Municipal Yenk Boox (1957). Numbers of such cities by type of LPA haye been calculated from data in Nat'z Ass'N of Housing and Redevelopalent Officials, Housing and Urban Renewal Directory (1958). 
government displayed no significant difference ${ }^{20}$ in tendency to arrive at final planning or execution stages, nor in tendency to drop out of the program.

2. Council-manager cities were underrepresented in the program but entered in increasing proportion in later periods.

3. Forms of government underrepresented among the early entrants tended to advance more rapidly once they had entered the program, but this difference was not statistically significant.

4. There were significantly lower percentages of the city LPAs and higher percentages of combined housing and redevelopment authorities among cities which had reached later stages of procedure. (This was explained by the later date of entry of more of the cities which were their own local public agencies).

5. Redevelopment authorities showed a significantly slower rate of advancement through the procedure than did either housing authorities or city LPAs. Possibly, however, the delays experienced by the redevelopment authorities were due to the necessity to organize a staff and to the litigation of the powers of these authorities.

The data showing later entry but swifter action by council-manager cities raises questions having to do with this form of government and the kind of community which adopts it. Presumably council-manager government gives less emphasis to differences within a community, while mayor-council government gives more emphasis to such differences. In council-manager governments, the council is more generally expected to arrive at some sort of consensus of views; the task of the council may even be interpreted as finding the best means to ends which are assumed to be agreed upon. In mayor-council government, on the other hand, continuation of differences may be more generally expected. In fact, one argument for a popularly elected chief executive lies in the presumed ability of such an officer to maintain the operation even while differences of view in the council are sharp and intensely felt. These dissimilarities in the two forms of government may affect the way in which they receive any new enterprises which bristle with thorny issues.

Thus, in council-manager governments, officials and other leaders may tend to place a higher value on maintaining the sense of agreement and so may postpone entry into a renewal enterprise until agreement is more certain. This caution may be all the more necessary where the balance of support for the council-manager plan rests on a shaky sense of general agreement or upon a none-too-convinced group who might be antagonized by some aspects of renewal. In mayor-council cities, leaders may be more ready to risk opposition, sceing it as inevitable and general consensus as impossible; they may, in fact, place a value on pointing up the disagreements which do exist in order to maintain party discipline, or even to prevent adoption of the council-manager plan. Perhaps, too, leaders of council-manager governments, placing a higher value on nonpartisanship, may have waited until they saw that

${ }^{20}$ Significant differences in the numbers of cities reaching various stages was indicated by a $\mathrm{Chi}$ Square of more than 3.84, under an assumption that 2 relation is significant when in 95 out of too cases, it cannot be attributed to chance. Chi Squares from 3.84 and 21.99 were calculated for the relationships summarized in the text. 
renewal had not only a Democratic version, but a Republican version as well (after 1952) before they risked entry into the program-not that council-manager governments are necessarily more Republican, but because their leaders wanted to avoid a partisan split.

The possibly swifter action by council-manager governments hinted at but not proved by the data might reflect the lesser ability in council-manager government of the lingering opposition to delay a program once adopted by a majority of the council. Weak-mayor structures of authority (found in some mayor-council governments) might make difficult the elimination of delaying tactics within the city governments even after adoption of a program by a majority of the council.

\section{IV}

\section{Crustered Case Studies}

To provide deeper insight into urban renewal achievement and its relationship to organizational structure and to other factors, case studies were made of twenty local renewal enterprises. Systematic comparisons were made in six groups of three cities-eighteen of the twenty. When each of a group of three cities is assigned a letter $A, B$, or $C$, the three following pairs of cities may be compared: $A B, B C$, and $A C$. The following steps were taken to make the pair comparisons systematic and to reduce bias.

The only cities included were those with less than a million population, having either mayor-council or council-manager governments. All had a reputation for renewal success with personnel of the appropriate regional offices of the HHFA. To make possible the grouping of judgments among as many different persons as possible, six different observers each contributed; their reports were then added up and are presented in the accompanying table. Each observer compared a city having a council-manager government with a city of about the same population size but having a mayor-council government; and also compared a pair of cities standardized for general form of government but contrasting in population size. Finally, each observer compared a pair differing in both respects-these being termed the "supplementary pairs."

Each observer confined his attention to cities having one type of LPA. However, the director of the study briefly visited cities with all three types of LPA and studied case reports to determine the effects of differences in LPA. Three of the observers confined their comparisons to cities within one HHFA region; three spanned two or more regions. The eighteen cities constitute at least ten per cent of all the cities in the category from which they were chosen.

Each observer began his studies in each city by preliminary review of documentary materials, followed by individual interviews with each of a panel of twenty-four persons occupying preselected public and private "positions in the community." In each city, on the basis of the early interviews (which tended to 


\begin{tabular}{|c|c|c|c|c|c|c|}
\hline \multirow{3}{*}{$\begin{array}{c}\text { Characteristic Taken as } \\
\text { Dependent, and Pairing Principle }\end{array}$} & \multicolumn{6}{|c|}{$\begin{array}{l}\text { Distribution of Pairs of Cities ayona Two Classes for Each } \\
\text { Characteristic Taken as INDEPENDENT. Showing Parina } \\
\text { Principle }\end{array}$} \\
\hline & \multicolumn{2}{|c|}{ Population Size } & \multicolumn{2}{|c|}{$\begin{array}{l}\text { General Form of } \\
\text { Government }\end{array}$} & \multicolumn{2}{|c|}{$\begin{array}{c}\text { Mode of } \\
\text { Coordination }\end{array}$} \\
\hline & Large & Small & $\begin{array}{l}\text { Mayor- } \\
\text { Council }\end{array}$ & $\begin{array}{l}\text { Council- } \\
\text { Manager }\end{array}$ & $\begin{array}{c}\text { More } \\
\text { Executive }\end{array}$ & $\begin{array}{c}\text { Less } \\
\text { Executive }\end{array}$ \\
\hline $\begin{array}{l}\text { Greater Achicvement } \\
\text { Standardized Pairs } \\
\text { Recent Achievement........ } \\
\text { Cumulative Achievement... }\end{array}$ & $\begin{array}{l}3 \\
5\end{array}$ & $\begin{array}{l}3 \\
1\end{array}$ & $\frac{2}{2}$ & $\begin{array}{l}4 \\
4\end{array}$ & $\begin{array}{l}7 \\
7\end{array}$ & $\begin{array}{l}2 \\
2\end{array}$ \\
\hline $\begin{array}{l}\text { Supplementary Pairs } \\
\text { Recent Achievement....... } \\
\text { Cumulative Achievement... }\end{array}$ & $\begin{array}{l}5 \\
4\end{array}$ & $\begin{array}{l}1 \\
1\end{array}$ & $\begin{array}{l}3^{* \#} \\
2^{* *}\end{array}$ & $\begin{array}{l}\mathbf{3} \\
\mathbf{3}\end{array}$ & $4^{G r o n}$ & 4 \\
\hline $\begin{array}{l}\text { All Pairs } \\
\text { Recent Achievement....... } \\
\text { Cumulative Achievement... }\end{array}$ & $\begin{array}{r}8 \\
10\end{array}$ & $\begin{array}{l}4 \\
2\end{array}$ & $\begin{array}{l}5 \\
4\end{array}$ & 7 & $\begin{array}{l}13 \\
11\end{array}$ & $\begin{array}{l}5 \\
6\end{array}$ \\
\hline 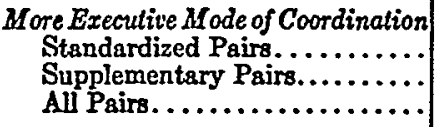 & $\begin{array}{l}3 \\
3 \\
6\end{array}$ & $\begin{array}{l}3 \\
3 \\
\mathbf{6}\end{array}$ & $\begin{array}{l}3 \\
1 \\
4\end{array}$ & $\begin{array}{l}3 \\
5 * * \\
8\end{array}$ & $\bar{z}$ & $\bar{z}$ \\
\hline $\begin{array}{l}\text { More Leadership by Cily Chief } \\
\text { Execulive } \\
\text { Standardized Pairs }\end{array}$ & & & & & & \\
\hline $\begin{array}{l}\text { Committed Activity......... } \\
\text { Leadership influence....... }\end{array}$ & $\begin{array}{l}2 \\
2\end{array}$ & $\begin{array}{l}4 \\
4\end{array}$ & $\frac{4}{5}$ & 1 & $\begin{array}{l}7 \\
8\end{array}$ & $\begin{array}{l}2 \\
1\end{array}$ \\
\hline $\begin{array}{l}\text { Supplementary Pairs } \\
\text { Committed Activity........ } \\
\text { Leadership influence....... } \\
\text { All Pairs }\end{array}$ & $\begin{array}{l}2 \\
4\end{array}$ & $\frac{4}{2}$ & $\begin{array}{l}\mathbf{0} \\
\mathbf{2}\end{array}$ & $\begin{array}{l}6 * * \\
4^{* *}\end{array}$ & $7^{G r o}$ & 2 \\
\hline $\begin{array}{l}\text { Committed Activity......... } \\
\text { Leadership influence........ }\end{array}$ & $\begin{array}{l}4 \\
6\end{array}$ & $\begin{array}{l}8 \\
6\end{array}$ & $\frac{4}{7}$ & $\begin{array}{l}7 \\
5\end{array}$ & $\begin{array}{l}14 \\
14\end{array}$ & 4 \\
\hline
\end{tabular}

Foludes two extreme instaqces of resk-mayor structures

- Includes two very small council-manager cities.

be with officials), the observer was free to make additions, and occasionally deleted from his inquiry some positions locally reported not to be participants in renewal.

To supplement objective data on achievement, the observers asked their respondents about the goals of the renewal plan, the problems which had been met, and the reasons for success; and they probed for the respondent's view of the adequacy of the urban renewal enterprise in respect to financial plan, organization, popular and administrative support market appeal, and concern for the interests of property owners, occupants, and the neighborhood.

'The observer's judgment on achievement was checked by reference to four available statistical measures. Neither the observers' judgments nor the statistical measures provided perfect standards for determining comparative achievement. The statistical data is objective in the sense that the quantities can be checked, but the standards are biased and insufficient in several specific ways, as well as in the implication that any one measure or small group of measures may-properly be applied to all renewal 
enterprises. ${ }^{21}$ Also, the statistical standards give no weight to the whole question of future continuity of the enterprise-whether or not it is a "one-shot" affair. On the other hand, the observers' judgments about achievement are personal judgments. They avoid the fallacy of applying one standard to eighteen different enterprises; and each observer attempted to develop a standard which would be appropriate for his three cities. The judgments reflect quantitative information and yet do not exclude factors not easily quantified-such as the prospective continuity of the enterprise and the suitability of the enterprise's strategy to the situation.

Actually, in most of the comparisons between a pair of cities, there was little question as to which had the greater achievement. A majority of the statistical measures differed from field judgment in four of the eighteen pairs. In all four cases, the larger city was given the higher achievement rating by the observer, quite in contradiction to the quantitative data, but for reasons which he defended, calling into question the relevance of available quantitative information.

Because the cities had not all entered the redevelopment and renewal enterprise at the same time, and because some greatly changed their formal organization along the way, it was necessary in some cases to distinguish recent or more comparable achievement from cumulative achievement (which in some cases could be traced back as far as 1950 ).

In studying the mode of coordination (ie., the degree to which coordination was executive in character), ${ }^{22}$ the observers, besides gathering documentary evidence,

${ }^{21}$ The four standards use the very limited data available: per cent of substandard dwelling units eliminated and per cent of city area in renewal projects, and ratios of $(r$ ) eliminated substandard units and (2) gross costs to population (per thousand). It would be better to relate project area to blighted area and to relate gross project costs to income. The several measures provide only a first stab at indicating how much of the total problem has been met, how much of the total task or workload has been shouldered, and how large and expensive the accomplishment and workload has been relative to the size or capacity of the community. More research is needed on the measurement of substantive accomplishment. Unfortunately all the data are for whole projects, not for the portions actually accomplished. This is a grave defect, since a project in planning is given as much weight as one in execution. Nonproject activity is not reflected.

22 Influenced by the doctrine of separation of powers, by the contrast in procedures between the executive and the other two branches, and also by the scope of their "reorganization" assignments, administrative analysts have concentrated their attention on the executive branch. By the time even the first textbooks on public administration were published, a common pattern was discernible in the recommendations for that branch: "integration." Despite criticism, this remains a very important doctrine in administration, perhaps its most easily defended version being the line-and-staff model.

To examine this model as it relates to urban renewal-and to put this model in its best light, while at the same time indicating some of its possible limitations for accomplishing urban renewal-several assumptions are made for purposes of this article. Assume, first, that a local legislative body (for erample, city council, commission, or board of aldermen) has entered upon 2 program of federally aided urban renewal; that this local governing body has approved a policy for urban renewal activities to advance on a planned basis through the city area by area, approximately in the order of the degree of blight and as rapidly as uncommitted financial resources, relocation opportunities, and other legislative policies permit; and that procedures exist for hearing recommendations from city executives and others permitting response and change in policies. Assume, next, that some other guidelines are also fairly well established, including a general citywide physical development plan; a capital improvement program coordinated with a schedule of debt retirement, a revenue system, and an executive budget; that there is a policy for reloeating those displaced in the course of any public works or activities; and that there are ordinances and an administrative structure for conducting municipal services, including regulatory codes. Finally, assume that the over-all structure of government is intended to utilize studies of conditions in ways which 
asked their respondents to describe how advice and information were supplief, whose reactions and attitudes were most important in the respondent's urban renewal decisions, and the ease or difficulty of access to such persons. That is, the observer sought chains of communication and authority. Sometimes frequent links of communication and authority were observed among people not within a formal chain of command. Sometimes the chain effectively ended at the level of a local government administrative or corporate board. Sometimes a superior did not have enough renewal information or the available information was not used to guide a subordinate's participation in urban renewal. In these and other ways, the coordination of the enterprise failed to be executive in character.

In the sense in which leadership was evaluated in these field studies, any participant in an urban renewal enterprise may be a leader in it-and perhaps most are. The degree of leadership is indicated by the degree to which the leader's relation to other participants tends to have consequences for change in the enterprise. Included as leadership are his influences on any or all of the structural elements of the enterprise, its program, procedures, or mode of coordination; the leadership may be exerted through actual communication, formal and informal, or simply through people's expectations of the leader's reactions.

One mark of leadership in an enterprise like urban renewal is "bridging." In bridging, leaders work together as an informal or only secondarily formal group to maintain and advance the enterprise by coordinating organizations and individuals which recognize each other's independence. To some degree, approval on the part of organizations in which the bridgers are members is merely anticipated-not previously and specifically granted by the organizations. .

According to the field studies, the "leadership influence". of the executive appears

belp to sustain citizen control of the local government and help to bring administrative practice into line with such policies.

Under the foregoing assumption, most of the larger issues of program planning for the municipality need not be fully resolved within the administrative system for urban renewal, since they have already been settled by policy decisions of the legislative body. Against this background, we can construct the following "executive model": All the major activities contributing to renewal objectives, including the activities conducted in each project area-such as redevelopment and areawide code caforcement-and certain citywide services-such as rehousing aid for those displaced from the projects-are placed in one department of city government, this department having at least as direct and privileged access to the chief executive as any other department. The chief executive of the city, a clearly defined office (whether manager or mayor), has formal powers of budget review and appointment and removal of the head of the department. The department head has similar powers over the major units within his department. Staff services exist within the department suitable for reporting and planning the department functions and staff officers for the department have direct access to the department head. Comparable arrangements exist in the city government as a whole. The staff services within the department are adequate ( $I$ ) to keep track of progress in each subordinate unit and alter instructions accordingly for other units so as to maintain coordination, and (2) to obtain data and offer plans for succeeding projects. The reporting procedures and staff units for program planning and adjustments are adequate for planning the municipality's use of each major type of scarce "resource," and there is a general category for all other needed administrative planning (such as is often assigned to a general "assistant to" the exceutive). No special provision is made for formal "citizen participation" in the locai government structure except in the governing board of the city; and there is no provision for "neighborhood" representation, unlessunder some sort of ward system-the governing board is itself wholly or partially constituted of such representatives. 
dominant more often in mayor-council cities than in council-manager cities. This, in turn, may reflect in part the previously remarked differences between mayorcouncil and council-manager governments with respect to extent of agreement prior to commencing an urban renewal enterprise. In a few cases, it might reflect a mayor's decision that urban renewal was a useful program on which to stake his political fortunes-with consequent maximization of the leadership efforts he put into achieving successful, and speedy, urban renewal.

And yet, by a very slight margin, greater achievement and "committed activity" by the chief executive appear to be somewhat more often characteristic of the council-manager cities than of the mayor-council cities. By a higher ratio, a more executive mode of coordination is found more often in the council-manager cities.

The results are ambiguous, however, because they appear to be affected by one systematic factor other than the form of government-namely, population size-as well as by some chance factors. The population factor may contribute to differences between the ratios reported for pairs which have been standardized to eliminate population contrast and supplementary pairs which contrast in population size. Inclusion of the supplementary pairs tends slightly to reduce the ratio for councilmanager cities with respect to achievement, and importantly to increase the ratios of the council-manager cities with respect to executive coordination of urban renewal, and committed activity and leadership influence of the city's chief cxecutive. Among the specific cities included in the supplementary pairs, two out of three of the council-manager cities happened to be much smaller than the respective paired mayor-council city. Also, among the mayor-council cities in the supplementary pairs, two out of three council-manager cities happened to be very much smaller than the respective paired mayor-council city; and, among the mayor-council cities in the supplementary pairs, two out of three happened to have an extremely weak-mayor formal structure of authority.

With all these factors in mind, we find that form of government is not decisive. From our survey cities we conclude that:

I. Achievement is not consistently associated with form of government, although council-manager cities have a slight "edge"

2. Mayor-council cities slightly more often than council-manager cities display the city's chief executive as the dominant leadership influence, while council-manager cities slightly more often display him as the most committed active leader.

3. The mode of coordination is slightly more executive in council-manager cities.

4. A combination of form of government and population size may affect the leadership of the executive and mode of coordination.

In respect to population size as the "independent variable," the observers found that:

I. Smaller population was accompanied by -primacy of the chief executive in committed renewal activity. No difference appears in the totals to indicate that size 
affects the chief executive's leadership influence. However, the standardized pairs show his influence greater in small cities. The tendency for mayor-council citics to thrust their chief executives ahead as infuential leaders may, therefore, somewhat obscure the greater leadership role of small-city executives.

2. Contrast in population appears not to affect mode of coordination.

3. Larger cities had the higher level of achievement, as judged by the observers. Cities were not preselected for similarity or dissimilarity in mode of coordination. The mode was determined only through the field studies. Lack of preselection has both advantages and disadvantages. When not preselected, all cighteen of the pairs instead of twelve are available for comparison, since we have not eliminated any pairs for known lack of contrast. On the other hand, when we do not preselect, we run the risk of finding very little contrast in mode, a contrast which, of course, would have been assured had we preselected for the purpose of displaying that contrast.

Taking the undifferentiated group of eightecen pairs, we find definite tendencies in respect to each of the characteristics studied. More of the cities with the more executive mode are judged by observers to have a higher recent renewal achievement, a higher cumulative renewal achievement, and to display the chief executive as more dominant in committed activity and also in leadership influence.

Since supplementary and standardized pairs showing mode of coordination as a basis for check were not available, another method was used. The eighteen cities were split on an arbitrary basis so that two groups of nine pairs each were identical with respect to the number having each preselected characteristic. This check (shown on the table) indicates that variability, though present, is not serious.

\section{$\mathbf{v}$}

\section{Change in Mode of Coordination}

The observers also sought to determine any tendency towards change in the manner of coordinating urban renewal as time passed and the enterprise progressed. While observations were far from unanimous, in most of the eighteen cities there seems to have been some trend toward a more executive mode of coordination. However, the requisite high level of activity by the chief executive in certain stages of urban renewal blurs this tendency. Also, it is sometimes obscured by the legal limits within which the local program operates.

Where the city is the LPA or where there is a redevelopment agency, "renewal coordinators" or "directors of renewal" tend to be set up for coordinating redevelopment and code enforcement. This is evidenced by the establishment of such offices and by the centralization of power to resolve differences affecting renewal. Where there is a housing and redevelopment authority, the authority itself usually develops from the outset along executive lines; and this does not change much as urban renewal progresses. In that situation, "bridging" is apparently used to coordinate the authority's activities with those of the local government; the bridgers tend to 
include commission members who govern the authority, councilmen, and even business and civic leaders without public office, as well as full-time officials. In some small cities, the planning commisssion serves as the chief coordinating group for urban renewal, and so makes unnecessary any other bridging groups.

In general, where there are local government administrative boards or corporate authorities, there is both a greater need for bridging to take place and a tendency for the chairman and the highest subordinates of boards or commissions with urban renewal roles to lead by bridging. On the other hand, where a chief executive leads the local government and there is a clear hierarchy of authority, there is much less need to bridge. Such bridging as there is tends to be performed by the city's chief executive and his chief subordinate for renewal.

In an agency headed by a board, if anyone is to lead in the coordination of urban renewal activities with other groups, including the local government, then it is reasonable to expect that function to devolve chiefly upon the board's chairman and its primary executive. They are not likely to disagree strongly with the majority opinion of the board, and are likely to know the agency's problems and needs in more detail than other board members and to possess more comprehensive knowledge than other subordinates. Accordingly, their views may receive considerable deference from board members, subordinates of the agency, and others who deal with the agency. In some instances, the authority accorded to a strong board with determined leadership may impair the ability of the city's chief executive to coordinate the urban renewal enterprise; and he may even lose control over the board to outside influences. At the same time, the board, particularly through the chairman, may win considerable additional support and exert added influence beyond the confines of city government owing to the board members' joint status as officials and as occupants of other positions in the civic and business life of the community.

The type of LPA is not easily changed. State law may provide no option. And even when it does, there is reluctance to change type of LPA when the existing one is effective or where new litigation would be required to test its powers. This inflexibility of LPA type tends to limit the trend toward a more executive mode of coordination in cities with corporate LPAs. Similarly, of course, a weak-mayor structure of city government may impede the emergence of an executive mode. Aside from these structural limits, there seems to be an underlying long-term trend toward a more executive mode for the enterprise. At the earliest stages in a renewal enterprise, caution impedes legislative delegation of authority to central management. The lack of central control appears to reassure those who fear that unwanted types of renewal might be imposed by a central executive. Perhaps these elcments feel safer as long as the agencies conducting different types of renewal must compromise and curry popular favor. Where rather evenly divided groups in the community intensely disagree on renewal policy, an executive mode is often avoided, or is adopted only in consiüerable controversy. This may be most important in cities where urban renewal is expected to extend over a wide area and where the exact nature 
of the future projects is not known. But a number of factors, including the planning process, encourage a more executive mode in the long run.

As ungrounded fears subside, restrictions tend to be withdrawn. State enabling legislation tends to be amended. As a result of this and their greater confidence, local councils become more willing to take responsibility and more willing to delegate authority, and executives more ready to accept it.

More important in the long-run is probably the progressive accomplishment of those renewal projects which are the easiest to achieve without central management. As the areas qualifying for federal aid and appealing strongly to the market are progressively renewed, the remaining areas become administratively more difficult to renew. And market funds may not flow so readily as before. Furthermore, the projects extend closer together and may require coordination of more varied renewal techniques. That is, the need for administrative coordination tends to increase even as the community's disagreements on renewal policy decline.

Neither the support nor the opposition to an executive mode which we noted exists at early stages of the renewal enterprise should be conceived as rooted ordinarily in public opinion. Most people may be unaware or only dimly aware of the issue. The people who participate actively in the enterprise tend to be most important in it. Some accord authority beyond the formal minimum to an executive only as program and procedures are evolved which are acceptable to them. The inspectors who may be chiefly committed to conservation and rehabilitation, but who also make the first contact with property owners in clearance areas, must overcome fear that a centralized operation would neglect conservation and rehabilitation. The housing authority employees who conduct relocation services on contract must overcome fear that a centralized operation might exclude public housing. The organized downtown interests, whose support is necessary in many ways, including, often times, the financing of the work, must overcome fear that a centralized operation would give insufficient emphasis to the surroundings of dowatown or would call for public housing on a scale thought by them undesirable. A more executive mode becomes a real possibility as early fears of these kinds are sloughed off by the potential committed active participants.

Contrary to the usual supposition, urban renewal does not tend to conform more closely to the executive mode in large cities. Indeed, it will be recalled that no significant difference was found in this respect among the cities of different size. The level of achievement was higher, however, among the larger cities, while the level of commitment and activity displayed by the city chief executive was higher in the smaller cities. Apparently there is a selection process which attracts small cities to the renewal program only when there is no strong local opposition to renewal, while in large cities, even intense opposition to certain types of renewal does not create a coalition capable of preventing or cutting of the renewal efforts altogether. Possibly a less executive mode has been actually more functional for the renewal enterprise in some large cities by assuring that there will be discussion 
and compromise before any particular renewal technique is applied in any specific area.

In those cities which enter the program with less than practically unanimous support, the city chief executive is encouraged to take active and committed leadership, but he may not find it necessary to bring much authority to bear. This would explain the greater commitment and activity without greater leadership influence of the chief executives of the smaller cities.

The greater achievement of the larger cities reported by observers appears to reflect, in part, the greater comprehensiveness of their renewal programs and their greater success in resolving policy differences. The smaller cities which entered the program had a less difficult problem to the extent that they, too, generally agreed on a project. But the observers were not confident that they would continue in the progiam with additional projects.

VI

\section{Type of Local Public Agency}

The chief operating agencies within an urban renewal enterprise, the redevelopment, code enforcement and rehousing agencies, present certain problems in organizing for urban renewal which are explainable in the light of their previous purposes. The three types of LPA utilized in urban development projects differ in their advantages and disadvantages for renewal. The differences were most important in the redevelopment period and in the first years of renewal. The housing and redevelopment authorities had staffs expcricnecd in the fields needed in redevelopment, including relocation, while their unfamiliarity with code enforcement and conservation made it difficult for them to develop a program that would give adequate attention to the potentialities of this form of renewal, and local opposition to many of them made it difficult for them to lead.

The availability of the city machinery for coordination and the established relations to. the city's political figures have been points favoring the city LPA in renewal, while their lack of familiarity with relocation and housing has made it difficult for them to develop relocation as an important and integral part of the program.

The redevelopment authorities have been free of fixed public attitudes but have lacked experience. Their formal independence of city hall gave them freedom to develop a fresh approach but threatened to leave them "out of the orbit of power and influence."

In actual practice, the disadvantages of each type have tended to be corrected, although not always soon enough to accommodate local opinion. City LPAs have learned renewal methods. Redevelopment authorities in many cities have proved amenable to central management control and have bcen brought under city government coordinators or administrators much more often than have housing and redevelopment authorities. Many of the housing and redevelopment authorities have 
learned the value of code enforcement. While the housing and redevelopment authorities have remained formally independent of city government almost everywhere, bridging groups have linked them with the city and have built more confidence on the part of business participants in the authorities. Even the corporate independence of the housing authorities, which, it will be recalled, was originally necessary if housing debt was not to be charged to the city's debt limit, can disappear where the state courts accept segregation of funds as a substitute for corporate separation.

In many large cities, the environmental code enforcement agencies have been scattered through the city government, and such agencies have been only rudimentary in small cities. Often, state regulations have been the only ones enforced in the latter. In cities of all sizes, the most vigorous enforcement program has sometimes been lodged in the health department, sometimes in the building inspector's office, and occasionally in a consolidated inspections department. Under the federally aided renewal program, widespread adoption of local housing ordinances, emphasis on area-wide enforcement, professionalization of the staffs, and consolidation or coordination of the chief enforcement agencies have been stimulated. In many cities, the city organization displays signs of reorganization for urban renewal chiefly in respect to the enforcement activities.

\section{VII}

\section{The Uraan Developaent Enterprise}

Currently, major new downtown rebuilding projects are taking their places alongside the more established neighborhood renewal efforts, and alongside the projects for construction of major transportation routes as the three major arms of a city program for the reconstruction of the urban environment. The reorganization for urban renewal must, therefore, provide for further evolution to accommodate a new enterprise. Not only is a more executive organization likely to be desirable for renewal in the long run, but the renewal organization must accommodate, at least in the largest cities, to coordinating arrangements for urban development as a whole. Staff, coordinating, and planning agencies will eventually be needed at this level in large and complex cities.

Many small cities in metropolitan areas do not tend to reach that point. They may contain no vast terminal complexes and not even border a major new transportation artery. Their whole area may be the size of a single renewal project. They may organize simply for renetual as a sufficient preparation for the emerging metropolitan-area-wide enterprise of urban development.

The cycle of adjustment of formal organization to enterprise and of enterprise to formal organization is occurring, then, once again. The tide of reform which swept across municipal government during three-quarters of a century fed on revulsion at the graft and corruption in public works as well as in other forms of boodle. As one result, departments of public works were created under professional engincers. 
Such departments, ever since, have offered a focus for planning and power to develop an appropriate network of streets and utilities.

As the tide of reform has swept away many of its own sources, and has gradually ebbed, the city governments have continued to evolve under the impact of newer enterprises. Several of these have contributed to the city government structures of today and to the enterprises which now engage the urban communities. To the use of police powers to close or demolish slum buildings was added the public housing enterprise' which replaces slum with publicly-financed, low-rent housing. Mortgage insurance was created and freed housebuilders to become mass producers and builder-developers who could develop whole "tracts," including the streets and sewers as well as the houses. Redevelopment constituted a new wave, offering to replace slums with any suitable new land use, public or private. Renewal was originated as another wave, offering a variety of treatments according to the character of the area. Currently we are in the midst of a new wave of programs for downtown reconstruction which utilize the renewal organizations and also the deparments of public works and other agencies concerned with transportation routes. And, if I am correct, we are now entering into another enterprise and a new cycle. This is an ambitious one. It is proposed to harness downtown reconstruction, urban renewal, and freeway construction to a grand strategy for governing the major elements in the over-all physical pattern of urban areas.

Because cities do not completely integrate the institutions for each new enterprise with the inherited institutions, one may trace the several stages of the civic evolution in the organizational structure of local government. The evolution may also be observed by comparing cities which entered upon all the successive enterprises with cities where some or all of these have failed to attract the community's interest. Some cities are just beginning to take urban renewal seriously. They may be the ones for whom the study of renewal experience may be most directly useful. Study of past experience may be equally relevant for those cities which have long since entered into a renewal enterprise and are ready for a newer urban development drama-but more to acquire self-knowledge, to see their past as prologue. They must also recognize the differences between renewal and the next enterprise. They must recognize, for instance, that the new enterprises envision the metropolitan areas as a whole, and challenge municipal government, even impertinently demanding its credentials as more than a pressure group within the urban community.

Our study stops short of these questions concerning organization for future enterprises. On the other hand, it prepares us to see organization for urban renewal as a problem for one of a series of "long waves" in civil life, each dominated by one or more major enterprises. Probably in each of these waves there is a phase when line and staff organization on the central management model is the most appropriate model. But an important frontier for administrative theory lies in supplying models 
appropriate for other phases, and in testing the effectiveness of the line and staff and other models for the necessary transitions, from phase to phase and from long wave to wave. The job of organization in those periods when the central management model is not acceptable is not to be dismissed vaguely as "politics" and "compromise." A whole course of organizational change is needed which will keep the structure in accord with political necesssities, including the necessity to serve a community's current enterprises. 